\title{
Decoupling in the age of market-embedded morality: responsible gambling in a hybrid organization
}

\author{
Susanna Alexius ${ }^{1} \cdot$ Giuseppe Grossi $^{2}$
}

Published online: 9 August 2017

(C) The Author(s) 2017. This article is an open access publication

\begin{abstract}
This paper contributes to the understanding of hybrid organizations by refining the concept of decoupling as a strategic response to conflicting objectives and institutional expectations (Meyer and Rowan in Am J Soc 83:340-363, 1977). In today's popular responsibility discourse one notes a hopeful "win-win" ideal that invites attempts, by companies in particular, to realize and balance conflicting values and to strive to fulfil both profit objectives and responsibility objectives. Although institutional theory has long acknowledged the strategic response of decoupling in organizational contexts, the potential of exploring and refining how this concept may be used to analyse strategic responses in the contemporary era of market-embedded morality has yet to be explored (Shamir in Econ Soc 37:1-19, 2008). There are good reasons to do so as the present-day discourse on the relation between the economy and morality offers a new set of options and challenges for legitimately responding to institutional demands. This paper draws on an explanatory, rich ethnographic and longitudinal case study of a Swedish fully state-owned company operating in the post 1990s gambling market. We suggest that contemporary hybrid organizations positioned at the crossroads of bureaucratic and market schemes of organizing, may find themselves in a particularly tight spot and seek legitimacy by decoupling — not only by adopting certain legitimizing structures, but also and increasingly with reference to market-embedded morality, a commoditizing of responsibility in their contested market setting. Based on the case findings, we
\end{abstract}

Susanna Alexius

susanna.alexius@score.su.se

Giuseppe Grossi

giuseppe.grossi@hkr.se

1 Stockholm Centre for Organizational Research (Score), Stockholm School of Economics, Stockholm University, Stockholm, Sweden

2 Department of Business Administration and Work Science, Kristianstad University, Kristianstad, Sweden 
suggest a distinction between organization-based decoupling and market-based decoupling and propose that market-based decoupling may be attractive to hybrid organizations owing to it being less sensitive to scrutiny and accountability claims. But at the same time, our findings indicate that market-based decoupling poses a risk to hybrid organizations, as it does not offer the same degree of legitimacy with key stakeholders/the general public as organization-based decoupling does.

Keywords Decoupling · Market-embedded morality · Hybrid organization - SOE · Gambling market $\cdot$ Sweden $\cdot$ Svenska Spel

\section{Introduction}

Being positioned at the crossroads of a wide range of multiple principal stakeholders, learning how to cope with accountability for conflicting performance objectives and demands is a core survival issue for hybrid organizations (Ebrahim et al. 2014). The opportunity to harvest legitimacy-enhancing elements of different institutional logics (for example, political and market logics) may help hybrids survive and thrive. However, this is a balancing act that also brings about much frustration and confusion to hybrids and their stakeholders (Brunsson 1994; Battilana and Dorado 2010). Hybrid organizations can take many different organizational forms, including public and private partnerships incorporating elements of state, market, and civil society (Billis 2010; Denis et al. 2015; Grossi and Thomasson 2015; Skelcher and Smith 2015). The increasing number of such hybrid organizations in recent decades is explained by scholars with reference to the increasing prevalence of pluralistic and complex institutional environments (Pache and Santos 2010; Thornton and Ocasio 2008; Bromley and Meyer 2015). Hybrid organizations need to design and manage their business models, strategies, and relationships to maintain their consistency in the face of the tensions between their identities, the conflicting logics they respond to and the practices they implement (Battilana and Lee 2014). However, how hybrid organizations select, prioritize and integrate plural institutional logics is still a topic in need of theoretical development (Kraatz and Block 2008).

The state-owned enterprise (SOE) is an interesting case of a hybrid organization with a dual complex mission in the sense that it is a limited corporation fully owned by the public, hence an organization operating on the border of the political and market spheres with their respective conditions and institutional logics (OECD 2011; Bruton et al. 2015; Grossi et al. 2015). Being positioned at the crossroads of the market and political spheres, the SOE is expected to generate both financial and non-financial values (Alexius and Cisneros Örnberg 2015) and to satisfy the interests of both its own customers and the interests of the government and broader public. As noted by De Geer (2011), SOEs are typically described as resources for governments to achieve goals in a wide selection of policy areas. Public services are often delivered by hybrid and complex organizations within policy sectors (for example, education, health care, utilities) where multiple state and non-state actors 
are involved in the design of policy and implementation (Arellano-Gault et al. 2013; Newman 2001). Along with profitability, an SOE can be expected to take into account regional, market-related, social or environmental aspects, and to safeguard particular interests in need of protection. This opaqueness or multiplicity of public sector goals often manifest themselves as partial confusion over organizational goals and strategy (Vining and Weimer 2016) as hybrid organizations tend to pursue explicit social missions through business-inspired strategies (Hockerts 2015).

Following the complexity of institutional demands, SOE boards and managers are expected to be able to interpret and balance different values and objectives as legitimately as possible (Ebrahim et al. 2014; Radon and Thaler 2005; Rainey and Chun 2005; Bruton et al. 2015). The tension or confusion concerning goals imposes a cognitive burden on boards and managers that demand reconciliation, for example, between global and local interests (Argento et al. 2016). In some countries, following recent OECD policy developments (Christiansen 2013; OECD 2003, 2015), governments openly encourage or even demand SOEs to act as moral role models for other corporations when performing this balancing act. However, this may be challenging, as in the market, legitimacy is mainly based on market mechanisms that focus on the profit economy and not on the need economy, which is the traditional focus of public sector organizations (Jonas 1984).

Drawing on a rich ethnographic and longitudinal case study, this article offers a vivid empirical illustration which has enabled a refinement of the theory on strategic responses to conflicting institutional demands (Oliver 1991). In particular, the article offers a further refinement of the concept of decoupling (Meyer and Rowan 1977) that enables a convincing explanation and fit to the altered conditions in the current era of market-embedded morality (Shamir 2008). The article raises questions as to the strategies used by SOEs to handle complex missions and demands of corporate social responsibility. To date, scholars have published only limited research on SOEs in leading management journals. Indeed, Bruton et al. (2015) have noted a lack of scientific studies of SOEs as hybrid organizations conducting business activities. Only a few studies have focused on hybrid organizations, and most of this research has had a public administration orientation (Koppell 2003; Billis 2010; Denis et al. 2015; Skelcher and Smith 2015). While the previous literature mainly refers to mixed public and private hybrids (Grossi and Thomasson 2015; Vining and Weimer 2016); the case organization discussed in this paper-Svenska Spel-is an SOE that is a hybrid by constitution as it embodies conflicting logics related to its structure as a limited corporation fully owned by the Swedish government. We analyse responses to this challenge by scrutinizing what happens over time in an SOE that operates in a contested market setting (gambling) and that is presented with a dual mission and expectations to act as a moral role model by organizing "responsibly" in the market.

In recent decades, socio-moral questions previously the concern of civil society and the political system have increasingly become "the business of market actors" (Shamir 2008). This development calls for a re-examination of the ways organizations - and hybrid organizations in particular-respond to conflicting objectives and institutional pressure. There is a lack of studies on how hybrid organizations' responses to conflicting objectives and demands are influenced by the 
altered conditions deriving from the increasing emphasis on market-based responses (such as sales of "responsibility labelled" products and services).

In this article we address this important topic by introducing a neo-institutional framework to strategic responses to institutional processes and by suggesting to link this theoretical discussion to the economic-sociological debate on how corporations in sensitive "concerned" markets (market exchange associated with negative externalities of some sorts) may earn legitimacy (Geiger et al. 2015). At a time when faith in market solutions to social problems is generally strong, and traditional bureaucratic restrictions and coercive sanctions have been seen as outdated in many contexts, we must be consistent in opening the black boxes of these market-based legitimation processes to scrutinize the outcomes (Cowan and Rizzo 1995; Fourcade and Healy 2007). In doing so, we must first acknowledge that organizing for legitimacy in a formal bureaucracy is different from doing so in a contested market setting (Alexius 2014). This is because, in markets, it is comparatively more difficult than in a formal bureaucracy to tell who should be responsible for what and why (ibid). Following from the fact that there is typically a lack of clear hierarchy and membership in markets (i.e. less clear who belongs to a market or not), market contexts are generally more open to organizing experiments in terms of how to achieve, judge and justify legitimate behaviour (Brunsson et al. 2015). In this article, we acknowledge that hybrid organizations face the challenge of standing with one foot in each of these worlds and their different conditions for legitimacy.

The text is organized as follows: Sect. 2 provides the theoretical framework based on neo-institutional theory and focuses on discussing the strategic response of decoupling in light of the novel conditions for hybrids in the contemporary era of market-embedded morality. The research methodology and data source is then set out in Sect. 3. Section 4 presents the empirical results of the case study and Sect. 5 offers a discussion of the findings and concluding remarks.

\section{Theoretical framework}

\subsection{Neo-institutional theory on decoupling}

The focus of much organization theory has been on the conditions and processes that facilitate the implementation and institutionalization of new ideas or structures in organizational practice. According to the still-prevailing rational ideal, for maximum legitimacy, each idea or structure formally decided upon in the organization hierarchy should optimally permeate the organization, from its management to its production processes, products and services. However, for the past four decades, ever since Meyer and Rowan wrote their seminal article on formal structure as "myth and ceremony" (Meyer and Rowan 1977), social science scholars have become increasingly open to and interested in demonstrating how strategic responses may vary from passive conformity to active resistance to institutional pressures, depending on the nature and context of the pressures themselves (Oliver 1991). 
In particular, critical organization studies in the neo-institutional tradition (Powell and DiMaggio 1991; Czarniawska and Sévon 1996) have shown that, in practice, it is often difficult to implement objectives, values and structures that are perceived to clash in some way with an organization's core values and operations. One way of solving this dilemma is to organize a separation of legitimizing formal structures from core operations. The strategic response of decoupling refers to instances in which organizations under pressure to adopt particular structures or procedures may opt to respond in a ceremonial manner, making changes in their formal structures to signal conformity, but then buffering internal units, allowing them to operate independent of these pressures (compare Scott 2014, p. 189). In light of Oliver's (1991) categorization of strategic responses, decoupling is seen as a strategy of compromise and as an attempt at balancing to "obtain an acceptable compromise on competing objectives and expectations" (Oliver 1991, p. 153). According to Battilana and Lee (2014) compromise could be achieved by separation. The authors discuss compartmentalization as one such separation strategy, and in this article we propose that decoupling is another vital separation strategy aimed to achieve a compromise between "multiple stakeholders and interests" (Oliver 1991, p. 153).

Decoupling is a common response to conflicting goals and expectations in all organizations (Greenwood et al. 2011) although the strategy is particularly relevant for hybrid organizations who, by their very constitution are heavily exposed to tensions and dilemmas generated by competing rationalities, values and logics (such as bureaucratic vs. market, public vs. private services; global vs. local). Decoupling is typically seen in cases in which a policy prescribed by external actors conflicts with internal institutionalized practices promoted by actors in the organization (Greenwood and Hinings 1996; MacLean and Behnam 2010). Solving this tension is critical for organizations that aim to acquire, maintain or restore legitimacy, not least towards government agencies, the state and lawmakers (Suchman 2005). A common response in such situations is thus to symbolically adopt the external policy while actually implementing the practice that is more coherent with internal organizational routines (Meyer and Rowan 1977; Oliver 1991; Fiss and Zajac 2004, 2006; Buck and Shahrim 2005; Yoshikawa et al. 2007; Pache and Santos 2013).

Empirical evidence of decoupling being used to gain or maintain legitimacy can be found in a variety of organizational contexts. Organizations have been shown to decouple especially during transitional periods when facing conflicting requirements related to different policies, including environmental, quality and auditing issues. In addition, organizations may find it difficult to persist with decoupling strategies for a long time. Moreover, decoupling may be difficult to sustain in contexts where institutional logics conflict in a temporary way. Decoupling is thus extremely relevant for hybrid organizations that are exposed to long-term institutional complexity requiring them to coexist with competing institutional logics over time (Pache and Santos 2013; Battilana and Dorado 2010; Denis et al. 2015). What we contribute to explore in this article is whether decoupling may be performed, not only on the micro-level of the organization but also on the meso- 
level of the market, and if so what characterizes and distinguishes these two forms of decoupling. This argument is outlined in more detail below.

\subsection{Decoupling in the age of market-embedded morality?}

The perceived relationship of economy and morality changes over time and space and has remained contested (Zelizer 1979, 1985, 2005). In recent decades of neoliberal regimes of government, public domains have been increasingly economized and we have seen non-financial value creation becoming increasingly overtrumped by, or expressed in terms of financial values in processes of commensuration (Espeland and Stevens 1998; Alexius and Tamm Hallström 2014). As a sign of the continuous balancing act of social life and its heterogeneity of values, the tendency to economize the social seems to have dialectically given rise to attempts to accentuate social values furthered by the economy. Emerging discursive formations, along with novel practices, have brought about a movement aimed to "moralize" markets in general and business enterprises and consumers in particular (Shamir 2008). This movement towards "market-embedded morality" characterized by attempts to "embed" morality into capitalist markets and the exchanges between buyers and sellers have been both praised and criticized by social science scholars.

A common starting point for many business studies of the contemporary Corporate Social Responsibility (CSR) movement is the assumption that selfregulatory initiatives contribute to the expanding of business actors' responsibility and accountability. However, a common critique when scrutinizing these claims and measures has been one of cherry-picking (Baden and Harwood 2012). Part of this critical debate has concerned the institutionalized spirit of capitalism and the willingness and capabilities of business enterprises to act socially responsible and to be accountable for economic externalities. Critical scholars have emphasized the influence of the "straitjacket of economic rationality" (Brooks 2010, p. 604) and have referred to common taboos in CSR discourses and practices (Kallio 2007). This stream of critical CSR-studies questions whether markets offer an effective mechanism for the social control of business and encourages us to open the black boxes of various CSR-measures and responsibility claims to scrutinize if perhaps, they produce "responsibility gaps" rather than fulfill expectations of an expanded responsibility and accountability for the social problem at hand (Alexius 2014).

Critical scholars (e g Miller and Rose 1990; Donzelot 1991; O’Malley 1996; Miller and Rose 1997; Rose 1999) have pointed out that general shifts in the distribution of responsibility-from the government to the private and civil sectors-have occurred in a number of countries and policy areas including pensions, welfare, and healthcare. These shifts have often drawn on discursive formations that center on a prospective (future-oriented) principle of responsibility distribution where the judgement and decision is based on an assessment of the expected future behaviour and capabilities, rather than on a more traditional retrospective judgement of past decisions and actions (Miller 2001; Bexell 2005).

As an empirical illustration of this discursive shift in recent decades, gamblingrelated harm is actively being constructed and reproduced in a hegemonic way that 
situates the main responsibility for the emergence and handling of gambling-related harm on the individual gambler and that relies heavily on the individual's capacity to control and adjust his/her consumption to prevent it (Alexius 2017). On a wider scale, numerous socio-moral questions - traditionally the concern of civic organizations, liberal-democratic parliaments, trade unions, and political parties-have increasingly become the business of market actors who offer responsibility-labelled products and services at the heart of the phenomenon of market-embedded morality (Shamir 2008). However, a key issue for critique has concerned the extent of consumer empowerment. Is it right to assume that consumer sovereignty is possible and if so, does it ensure social responsibility in business via the market mechanism? (Smith 1990/2015). Summing up, the shift towards market-embedded morality (morality embedded in market actors and their exchange of, in particular, responsibility-labelled products and services) is interesting as it is a subtle yet potentially powerful governance technique for shifting responsibility for societal shortcoming and the downsides of economic exchange onto individuals. This is done in a prospective manner that emphasizes consumer capabilities to make informed choices to self-manage and self-regulate social risks (Rose 1999).

In today's popular responsibility discourse one notes a hopeful "win-win" ideal that invites attempts, by companies in particular, to realize and balance conflicting values and to strive to fulfil both profit objectives and responsibility objectives (Garsten and Sörbom 2014; Nyqvist and Thedvall 2014). Although institutional theory has long acknowledged the strategic response of decoupling in organizational contexts (Meyer and Rowan 1977; Oliver 1991), the potential of exploring and refining how this concept may be used to analyse strategic responses in the era of market-based morality has yet to be explored. There are good reasons to do so as the age of market-embedded morality offers a different set of options and challenges for legitimately responding to institutional demands.

Previous studies on decoupling have traditionally focused on decoupling within a formal organization (organisation-based decoupling), typically decoupling from core operations to a specialized department designated for a certain institutional demand. When an organization faces conflicting institutional demands, it is common for the organization's management to invest resources in creating or strengthening a particular responsibility department, where activities are pursued under the popular labels of "CSR" and "sustainability" and are aimed at promoting and communicating that the organization is taking a greater responsibility. The typical rhetoric is then that the CSR department will serve as the engine for that organization's responsibility work, the force that ensures that responsibility is not only communicated externally but that it also permeates the organization's internal areas in their entirety. But in practice, this ambition often stops at just that-an honourable ambition. Instead of responsibility permeating the entire organization and being seen as an obvious precondition for generating profit, the responsibility work can be isolated to the CSR department, where it manifests as rationalized myths and ceremonies (Meyer and Rowan 1977) that are retold and celebrated in the organization's separate "display cases" - for example, in its CSR or sustainability reports. 
Many organizations also attempt to respond to conflicting institutional demands and value conflicts by taking a preventive, informative stance with respect to responsibility (Meyer 1996) and by decoupling such claims internally (Meyer and Rowan 1977), for example by strategically delimiting the permeating ambition to a part of the core business, a separate "niche range" of products and services labelled more responsible or sustainable. These goods are then developed as an alternative or complement to the organization's regular product range. Another related, more radical, but not uncommon variation on the above niche range theme is seen when an organization's stakeholders are offered options for responsible exchanges without the organization itself modifying its core products and services in any way. This can be a matter of offering responsible "accessories" for its risky or otherwise controversial products. For example, it can be a question of protective clothing for motor cyclists. This organizing solution, which has received less attention in the literature, implies that corporations have the option of decoupling their responsibility work from the core business in their contested market - by referring to or themselves helping to organize a "side-market" for responsibility services and responsibility products that can be seen as a kind of decoupled solution to the legitimacy problems and lack of responsibility of the primary market (Jutterström et al. 2014). The market for trading emissions permits is an example of such externally decoupled responsibility, created to address critique in primary markets like the markets for coal, electricity and metal products (ibid). Instead of banning an industry or practice or forcing an organization to take more responsibility, this is a question of attempts to address the primary market's responsibility problems through supply and demand-by packaging and offering responsibility on a voluntary basis: "Responsibility for Sale!" By ascribing an economic value to the non-economic value "responsibility", responsibility can thus be commodified - made into a product that can be marketed and offered in the market (Zelizer 1979, 1985, 2005; Shamir 2008). To conclude this section, both organizationbased and market-based decoupling are strategic responses that may help organizations with complex value-laden missions-such as hybrid organizations-to be perceived as legitimate actors. However, the usefulness of this conceptual distinction is yet to be explored. The next section on methodology outlines our thoughts on how this endeavour could best be realized.

\section{Research context and method}

Case studies are generally a well suited methodology to capture the dynamics of organizational life (Eisenhardt 1989) and tend to be most valuable when the researchers are clear about their initial theoretical position and at the same time remain open for theoretical modifications, based on tentative rounds of case analysis (Otley and Berry 1994). In explanatory case studies, theory is useful insofar as it enables the researcher to provide convincing explanations to the case practices. If however available theories do not provide adequate explanations, it will be necessary to modify such theory or develop new theory (Scapens 2004).

The case study on the Swedish fully state-owned enterprise Svenska Spel presented in this paper draws on and was conducted as part of extensive 
ethnographic and longitudinal fieldwork on the organizing of responsibility in markets. The Swedish gambling market during the period 1990-2015 was studied and particular focus was placed on following the establishment and handling of the phenomenon of "gambling addiction" as an externality problem of essence to the legitimacy of the market. The overarching aim was to provide a rich empirical account of the most influential events, organizers, ideas, exchanges, norms, rules and representations that, starting at the end of 1980s, contributed to changing the general understanding of the externality problems in focus, the distribution of responsibility and the forms of responsibility organizing. Who and what influenced the organizing of responsibility? Who or which parties were made responsible? For what, on what grounds and by what means? During the fieldwork, "gambling addiction" was not treated as a self-evident problem, naturally contingent on gambling-market practices. Rather, the ambition was to analyse how it is that this externality has come to be represented and perceived in this way (Beronius 1991; Bacchi 2009).

Although the case study of Svenska Spel was commenced with the purpose to explain how a hybrid organization deals with its dual mission, the ethnographical and longitudinal field work inspired us to refine the existing theory on strategic responses to institutional demands. In particular, tentative findings prompted us to suggest a conceptual refinement of the central concept of decoupling (Meyer and Rowan 1977). Analyzing the data in light of the literature on market-embedded morality then further enabled us to see the more general potential of such a conceptual refinement.

The case study used ethnography as a research methodology constituted by multiple data collection methods-participant observations, interviews, and archival sources. As a research method, ethnography is well suited to the understanding of the dynamics and the processes of change, as it allows a researcher to engage with organizations and the broader field in a way that enables a more comprehensive understanding of, for example, how change unfolds over time and how practices relate to intended reforms (Adams and Larrinaga-Gonzalez 2007).

The empirical material collected and analysed during the entire fieldwork in the Swedish gambling market included document studies, 40 verbatim transcriptions of interviews conducted in 2007-2010 with key informants in and around the market (including representatives of gambling operators, NGOs, public authorities, care providers, gamblers and journalists), and added to these, dozens of more informal conversations. The size, full state ownership, and hence status as hybrid organization of significant influence in the contested Swedish gambling market, motivated a special focus on Svenska Spel's institutional responses and claims to morality via its responsibility work. Of the 40 face-to-face semi-structured interviews, 18 were conducted with Svenska Spel employees and board members. To enable further nuances and triangulation, 15 participant observations of responsibility work in and around the market were conducted in 2008-2009 and in 2013 at gambling operators, their agents in shops, restaurants, bingo halls and casinos, at treatment facilities in primary care and private institutional care, and at the national support association for gambling addiction. Five of these participant observations were conducted at Svenska Spel. As for documents, these comprised 
thousands of pages of bylaws, policies, government appropriations, newspaper articles, annual reports and other external reports, including CSR and responsibility reports from the gambling operators studied, covering the years 1998-2012 (including documents from Svenska Spel and its predecessor Tipstjänst, the Swedish Gambling Authority, the National Institute for Public Health and the national support association for gambling addiction, SBRF).

The interviews were all taped, transcribed, coded and recoded to ensure that all instances of the interview text relevant to the topic guide were retrievable. Field notes were taken during participant observations and comparative analysis (mainly qualitative, partly quantitative) was then carried out on emergent themes, which were used as input in subsequent studies. Letting time pass between rounds of analysis provided time for reflection, enabling the discovery of new meaningful patterns (Davies and Harré 2001). All interviews were conducted in Swedish, and relevant sections were translated by a professional translator. All in all, the fieldwork provided a rare opportunity to follow over time how central organizations in a contested market, with the fully state-owned gambling company Svenska Spel in a pivotal role, have responded to the criticism of lacking responsibility for the downside of the market, with an emphasis on fraud and health issues (Alexius 2014).

\section{Svenska Spel and the dual mission of responsible gambling}

\subsection{Historical background}

The exchange of gambling products has always been a sensitive, value-laden policy area (Reith 1999; de Goede 2005; Ihrfors 2007; Hong and Kacpercyk 2009; Husz 2004). Looking specifically at the Swedish context, Alexius et al. (2014) identified three transformative moments in the market between 1830 and the present- "immoral gambling" (approx. 1830-1844), "remoralization of gambling" (approx. 1920-1940) and "emerging health concerns" (approx. 1995-ongoing). In the third transformative moment, social health concerns were increasingly framed as connected to the exchange of gambling products (Helling 2003; Ortiz 2006). Three events contributed to putting the problem of "gambling addiction" onto the political agenda: Sweden becoming a member of the EU in 1995, the publication of the first Swedish prevalence study on gambling addiction in 1999 and the Internet boom that followed shortly thereafter (Alexius 2014).

Time after time from 1994 onwards, the European Court of Justice (ECJ) had ruled that a gambling monopoly like the one in Sweden could be justified only if its purpose was one of protection (Schindler 1994; Läärä 1999; Zenatti 1999; Gambelli 2003), more specifically, the effort to limit the exploitation of people's desire to gamble and to reduce the risk of crime and fraud. The historically central purpose of state gambling activities-bringing money into the state coffers-could from this time forward only be a positive "ancillary consequence" and not the sole purpose (SOU 2000:50, 2006:11, 2008:124).

The net gaming revenues in Sweden were constantly growing from 12 billion SEK in 1995 to more than 16 billion in 2015 (Table 1), and in the same year (2015) Svenska Spel with Casino Monopol reached almost $50 \%$ of the regulated market. 
Further shaping this transformative moment, in 1999 the first Swedish prevalence study on gambling habits and addiction estimated that at least 100,000 people in the country (of a total of around nine million) had experienced direct negative economic, social, personal and health consequences caused by their gambling. About the same time the ongoing expansion of online gambling became a worrisome threat to government monopolies around the world. Despite the rulings of the ECJ and the findings of the prevalence report, the Swedish Parliament subsequently chose to launch new gambling products. First the decision was taken to reintroduce the Video Lottery Terminal (VLT) gambling machines that had been banned in the 1970s. It was then decided to establish four international casinos in the country. The licences for these new products were given to Tipstjänst, the larger of the two state-owned gambling companies. In the decades to come, as described in the case below, the state-owned gambling operator Svenska Spel ("Swedish Games" - the result of a merger between the two SOEs Tipstjänst and Penninglotteriet in 1997) took active part in successful attempts to reframe the contestation of gambling by increasingly emphasizing the role of "responsible gambling" as a customer-centred approach to handling the criticism (Alexius 2014).

Table 1 Net gaming revenues in Sweden, mSEK. Source: Lotteriinspectionen Statistics (2017)

\begin{tabular}{|c|c|c|c|}
\hline & Regulated market & $\begin{array}{l}\text { Svenska Spel, excluding } \\
\text { Casino Cosmopol }\end{array}$ & $\begin{array}{l}\text { Casino Cosmopol } \\
\text { (Svenska Spel) }\end{array}$ \\
\hline 1995 & 12,015 & 5904 & \\
\hline 1996 & 11,890 & 5675 & \\
\hline 1997 & 12,254 & 5878 & \\
\hline 1998 & 12,824 & 6396 & \\
\hline 1999 & 13,144 & 6412 & \\
\hline 2000 & 13,914 & 7281 & \\
\hline 2001 & 15,063 & 8453 & 33 \\
\hline 2002 & 14,347 & 7682 & 304 \\
\hline 2003 & 14,721 & 7880 & 720 \\
\hline 2004 & 14,638 & 7909 & 853 \\
\hline 2005 & 14,079 & 7600 & 922 \\
\hline 2006 & 14,603 & 7904 & 1002 \\
\hline 2007 & 15,704 & 8396 & 1153 \\
\hline 2008 & 15,956 & 8532 & 1224 \\
\hline 2009 & 16,673 & 8677 & 1198 \\
\hline 2010 & 16,947 & 8433 & 1190 \\
\hline 2011 & 17,267 & 8484 & 1203 \\
\hline 2012 & 17,288 & 8629 & 1186 \\
\hline 2013 & 17,248 & 8562 & 1167 \\
\hline 2014 & 16,446 & 7782 & 1159 \\
\hline 2015 & 16,717 & 7781 & 1180 \\
\hline
\end{tabular}




\subsection{Svenska Spel: hybrid organization with a dual mission}

The critical discussion regarding the state monopoly's responsibility for the downside of gambling had already begun during his predecessor's years, but in the autumn of 2004 it fell upon Jesper Kärrbrink, Svenska Spel's new CEO, to take market shares in the less regulated and rapidly growing Internet-based market place, and preferably at no social cost. The double-edged mission from the owner, the Swedish government, was for Svenska Spel to sell entertaining games, preferably with increased revenues. But this was to occur while maintaining a strict balance between responsibility and profitability.

Svenska Spel's mission is to offer responsible, safe and entertaining games to the Swedish population [...] We find it evident that commercial thinking and responsible behaviour in society go hand in hand. (Excerpt from Svenska Spel CSR Report 2004)

In its corporate governance, the Swedish government emphasized how Svenska Spel, being an SOE, had a special capacity to manage a complexity of values and hence better chances than the ordinary, private limited firms to successfully fulfil the dual mission of selling appealing lotteries and games without risking additional social costs. How this responsibility was to be organized in practice, however, was nonetheless far from given (Forsström 2010; Stymne 2010) - and as the reader of this case will soon notice, in the years to come, Svenska Spel would use both organization-based and market-based decoupling to respond to their dual mission.

\subsection{Responsibility that permeates!}

According to the Svenska Spel board's interpretation of the increased Internet competition in the early 2000s, the "grow to maintain" strategy called for a continued strong marketing push (Gustafzon, interview). According to this strategy, the company should focus on attracting and keeping customers with a low to medium risk profile, called "green players"-players who (still) saw gambling as entertainment. See, for example, this excerpt from the Annual report of 2007:

Svenska Spel's gambling responsibility relates to providing players with information, knowledge and specific tools to take control over their gambling.

In other words to not go from green to yellow or red.

From the outset, the stated objective was for Svenska Spel to become "world-class" in "responsible gambling". By way of effective "responsible gambling" initiatives, Svenska Spel would serve as a "responsible social actor" and preferably distinguish itself in a positive manner from other gambling companies, both the nationally regulated and those operating in the global e-market. In the company's 2004 CSR report, under a heading entitled "Balance between profitability and responsibility", Kärrbrink officially explained his view of the complex mission: 
Our fundamental values demand that we strike a balance between profit and responsible gambling. Maximization of profits is not an end in itself and should not be sought at the cost of offering products that make it difficult for people to control their gambling. [...] Responsible gambling should permeate all of our activities, from product development to marketing. We are at the forefront of developing responsible gambling and our long-term ambition is to be looked upon as a world leader in the field.

In this official statement, a rational perspective on decision-making and its influence on an organization is communicated, as Svenska Spel emphasizes that the dual mission should permeate the entire organization, including the core operations. Following this outspoken rational ambition, in 2004, marketing costs for billboards and TV advertising were reduced by $20 \%$, and Svenska Spel gave up revenues when about 200 VLT (Video Lottery Terminal) machines were relocated from "unsuitable" restaurant locations where gambling had become much too dominant, according to the public authorities. Other examples of concrete measures of a restrictive nature that influenced core operations included betting limits, the option of voluntarily blocking oneself from games, an account-blocking option, and restrictions on operating hours. "Sensitive games" were given age restrictions, random test purchases were conducted, and the company worked to prevent credit play and to promote "healthy gambling environments".

Svenska Spel's management also responded to the institutional demands by setting up a separate CSR-team to coordinate the responsible gambling issues. The new team reported directly to the CEO. The outspoken ambition was for the responsibility work to be so integrated in the organization that it would truly permeate it and become an obvious part of everyone's work (Forsström, interview). The CSR staff started off by inviting the management teams of the different business areas to workshops where they were asked to formulate a vision and to come up with a number of concrete objectives and key performance indicators. However, despite these goal-focused efforts, it soon proved difficult to find sponsors for the responsibility work in the organization. For CSR manager Petra Forsström, the internal responsibility integration became taxing as it became clear to her that many employees felt that the responsibility work lacked clarity and was often experienced as negative or unimportant. She recounts in an interview how people would even try to "duck out of sight" when they saw her coming (Forsström, interview).

Svenska Spel also responded to institutional demands by taking a more active role in the at-times stormy policy debate. In newspaper articles, commentaries and in the public conversation, Svenska Spel employees did their utmost to explain the company's mission and responsibility position. The communication included key phrases like "increased knowledge" and "greater awareness". Many meetings were held with stakeholders at home and abroad, above all with the other legal operators in the Swedish gambling market, gambling addiction support groups, the Institute for Public Health, the Swedish Gambling Authority, gambling researchers, social services, care institutions and other stakeholders, as well as internationally at the World Lottery Association (WLA) and European Lotteries (EL) (Svenska Spel 
Annual reports 2005-2010; Forsström 2010). Despite these many meetings, it was still seen as relatively open to interpretation what responsibility the fully stateowned gambling firm actually had to protect the players and how this responsibility should be organized in practice (Forsström, interview; Forsström 2010).

\subsection{Responsibility before profits? First signs of organizational decoupling}

That responsibility issues had a special place in CEO Kärrbrink's heart was an often-repeated sentiment. Anyone listening carefully could however soon hear him describe the "responsibility before profit" strategy as the company's most commercial strategy and there was increased emphasis on the Svenska Spel brand, (rather than its financial and non-financial results):

The Svenska Spel brand should convey a sense of security [...] We have a long-term ambition of distinguishing ourselves from other gambling companies in the Swedish market by being seen as a world leader in responsible gambling (Svenska Spel i samhället, CSR-report 2004, p. 4, 6).

Social responsibility is a natural part of our culture and an increasingly important competitive advantage. [...] we are working hard to make our focus on responsible gambling an even more prominent part of the Svenska Spel brand (Svenska Spel Annual report 2005, p. 14-15).

In a matter of a few years, the CSR team merged with the rapidly growing communications department at Svenska Spel. The internal workshops and initial ambitions of a permeating responsibility with a high degree of involvement and ownership in core operations, were less emphasized as external communications and branding became core priorities.

\subsection{Market-based decoupling: responsibility as innovation of self-help tools}

In the beginning of 2006, following a poker boom, approximately 180,000 Swedes were playing on foreign-based online gambling sites and the question arose how Svenska Spel should respond, considering rapidly increasing global Internet competition. When Svenska Spel eventually received approval from the government and launched its own online poker games in March 2006, it was a product with a competitive rake and an innovative "built-in" self-regulating responsible gambling tool. No poker game could start until a player had filled in the required information about his/her gambling budget: how much money the player was prepared to lose per day, week and month, and how much time-per day, week and month-the player was prepared to spend playing. Once the gambling budget had been set, it was not possible to raise the limit or increase the number of playing hours until the current period registered in the system had lapsed. Requests to reduce one's budget or number of playing hours, on the other hand, went through immediately. Additional responsible gambling tools, such as collective breaks, were also built into the gambling product. When commodifying responsibility in this fashion, Svenska Spel took a first step into the modern arena of market-embedded morality 
where different measures to tackle sensitive market externalities (such as gamblingrelated harm) are expressed as products and services on sale in the moral economy.

Between March and December 2006, approximately 137,000 customers played on the Svenska Spel poker site, and by December its national market share had climbed to about 30\%. When Svenska Spel's online gambling was growing faster than its competitors', despite its higher price and lower payouts, Svenska Spel interpreted this as a sign of a potential demand for "responsibility-labelled" gambling product and as a confirmation that market-based responses of this kind were well-received.

In September 2006, there was a change of governments in Sweden, whereby a conservative alliance took over from the former social democratic government. The reins of finance minister were then turned over to the more gambling-sceptical, conservative Anders Borg. Things had been different under previous Minister of Finance Bosse Ringholm's years. Compared to Borg, Ringholm came across as a gambling enthusiast. Of likely significance in this context is also that Ringholm and Svenska Spel's board chairman, Anders Gustafzon, were old friends from their days in the Swedish Social Democratic Youth League. Ringholm had thus acted as a personal link to the Ministry of Finance and the government. Borg, on the other hand, took a more wait-and-see approach and let Svenska Spel wait over a year before an owner dialogue took place. This delay led to frustration in the gambling company's management, which was trying to plan for an uncertain future. For despite the special efforts, Svenska Spel's online poker had attracted political criticism from abroad. The EU Commission deemed the poker venture a failure to meet treaty obligations in accordance with EC law-a criticism that could not be taken lightly. Pending an owner dialogue, Svenska Spel, however, continued full steam ahead. The company applied for permit after permit and had ambitious longterm business plans for exporting games abroad, if the government owner would only allow its fully state-owned enterprise to do so.

\subsection{Spelalagom.se: separate website for responsible gambling tools}

While waiting for an owner dialogue and the findings of the online poker commission, the Svenska Spel management found reason to take additional responsibility measures (Gustafzon interview; Palmgren interview; Kärrbrink interviews). The company launched its "Play in moderation!" (Spela lagom!) slogan and a separate website with the same name-spelalagom.se-offering an entire portfolio of responsible gambling services referred to as "tools", all of which were in line with keywords like "voluntary" and "individual responsibility". Along with the usual gambling products, the idea was that customers of the state gambling company would be given access to a suite of free training and tools to ensure "moderate" (lagom), balanced and responsible gambling. As Maria Schubert, part of the CSR team of the Svenska Spel communications department later expressed it (Schubert, interview):

In order to prevent unhealthy gambling, we offer a series of tools that help our customers make good decisions about their gambling. 
But, as opposed to the "responsibility-labelled" poker, which had been launched as a ready-to-use niche product for responsible gambling, the responsibility tools (including a gambling budget tool, self-test and the timer function) were now clearly separated from the company's core products and operations in the sense that they were not built into the games themselves. Furthermore, these tools were now presented on a different website, separate from the main site www.svenskaspel.se where gambling sales took place. This is a clear example of how organization-based decoupling (setting up a different website on responsibility to respond to external pressure and letting this website be isolated from the ordinary website) may be combined with market-based decoupling (producing preventive tools and information on responsible gambling that are offered-in a market-like fashion-as products and services targeting consumers). In short: the commoditized responsibility was now being offered on a site separated from Svenska Spel's usual sales of games. The official justification for this decision was not to tempt problem-gamblers in need of help to buy new games. But there was also a risk that consumers about to develop an addictive behaviour would not find the tools and services in time. An internal, anonymous critique, claimed this could be seen in light of the company slogan "spela lagom-play in moderation" meaning gambling not too much, but not too little either."

In the autumn of 2006, Svenska Spel intensified its efforts in "responsible gambling services" even further. Starting in late summer, first steps were taken towards what would eventually become the "Playscan" (Spelkoll) tool. The background to this tool was the external criticism and a discussion about Svenska Spel's marketing. Up to this time, the company had worked proactively, through its customer relations management for example, to find customers that played "too little", to remind them that they could play a bit more. Encouraging increased play in this way was seen, internally, as uncontroversial if the marketing targeted the $98 \%$ of all customers who, based on the 1999 prevalence study, could be described as low risk, "green” players. But CEO Kärrbrink's ambition was now to go even further and create a tool that could identify the remaining $2 \%$, the "problem gamblers". He envisioned a kind of "breathalyser" for gambling. Kärrbrink became interested in the possibility of identifying gamblers with a so-called reverse "churn profile"-i.e. customers who suddenly began to buy significantly more and more often than previously. As these customers were likely on their way to becoming problem gamblers, it would be a good thing, for both social and long-term economic reasons, to try to warn these customers in time, before Svenska Spel ended up losing a good customer and risking their social mission. As Kärrbrink recalls having described it to the board (Kärrbrink, interview 1):

So I'm sitting here and have been playing normally, and then something happens in my life that makes me play more and more. It may just be that there are a lot of interesting games right then, like World Cup soccer, that I'm a big fan of, or something... that I don't have anything to do, I want to escape a boring everyday life or something. And then "ping" [sound effect]— "If you keep playing in this manner ...". Well, yes, I've actually played a bit much ... 
maybe I should make a budget. Maybe I'll stop playing poker, take a threemonth break.

In close collaboration with advanced mathematicians and gambling psychologists, Svenska Spel initiated a project tasked with coming up with a model that could get players to remain in the "healthy, green gambling zone", as they expressed it (Cederberg, interview). At the bottom of this construction lay a cognitive behavioural theory-inspired self-test. Based on a player's current gambling attributes, it was able to predict what his/her gambling behaviour would look like over the next three months so as to warn the player while he/she was still rational and receptive. Kärrbrink envisioned a comprehensive system that could be offered as an accessory to all types of games in the Svenska Spel group and hoped that this would give Svenska Spel a competitive advantage pending any future regulation changes in the gambling market (Kärrbrink, interview 1). These were additional steps taken to separate Svenska Spel's core operations from its responses to the down-sides of gambling-related harm.

\subsection{Political criticism}

However, the company continued to receive the cold shoulder from the government. No owner dialogue and no new permits. A reason behind this frosty relation was the EU Commission's repeated accusation and questioning of how the Swedish state was fulfilling its protective intent concerning the risk of gambling-related harm. The Commission now threatened to bring Sweden before the ECJ if Finance Minister Borg failed to demonstrate responsibility: a Svenska Spel that protected its citizens-not a state-owned gambling company whose core purpose was to make money. For as seen in Fig. 1, ever since the merger that created Svenska Spel, the

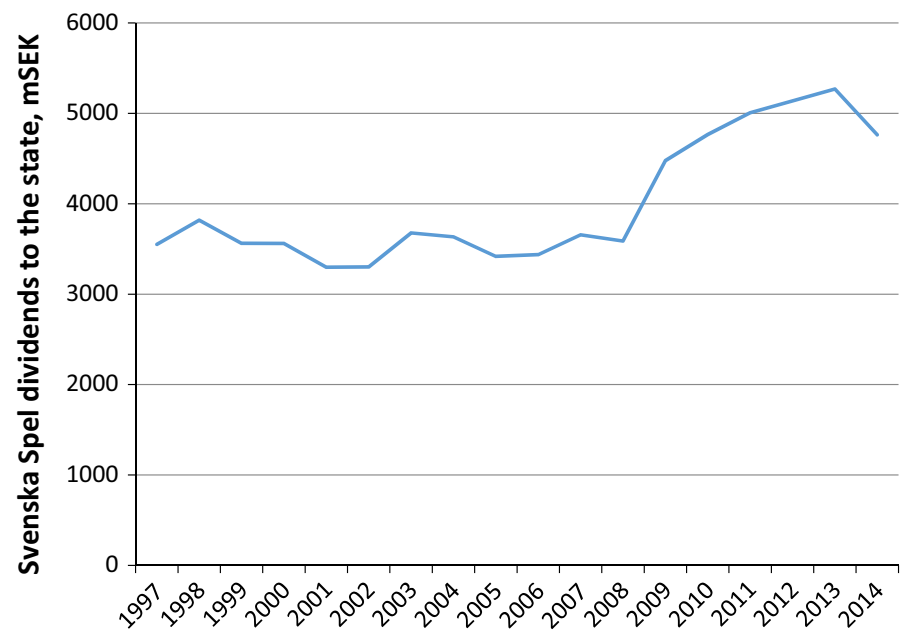

Fig. 1 Svenska Spel dividends to the state 1997-2015, mSEK. Source: svenskaspel.se, regeringen.se 
state-owned gambling operator has provided a solid contribution to the state budget. And although the numbers have fluctuated a little over the years, the Svenska Spel slogan "responsibility before profits" is not easily seen in this figure.

On 20 June 2007, almost a full year after the stinging EU critique, yet another public gambling investigation was launched and the message from Borg and Minister of Public Health Maria Larsson was clear: Don't rock the boat until the pressure from Brussels eases! (SvD 2007-06-20). It was a final official warning. Some nine months later, on the evening of Thursday, 3 April 2008, Kärrbrink received two earth-shattering calls. The first to contact him was board chairman Gustafzon, who informed Kärrbrink that Gustafzon would probably have to step down from his position. Shortly thereafter came the second call, from the communications director, who informed Kärrbrink about a press conference on the future of Svenska Spel to be held at the Ministry of Finance the following day-a press conference to which they had not been invited. Kärrbrink watched the press conference broadcast live on a web channel. He heard the Minister of Finance say that Svenska Spel was not performing its duties, that the company was not taking enough responsibility, and that the government would therefore change chairmen and strengthen the focus on social responsibility and public health. When the Minister of Finance criticized the responsibility work that Kärrbrink felt he had invested heart and soul in over the previous four years, he decided to resign (Kärrbrink, interviews; Gustafzon, interview). In a media interview, Kärrbrink communicated and explained his decision (SvD 2008-04-21):

We've chosen to invest a great deal in social responsibility and do more than all other gambling companies in the world do. At the same time, we've focused on maintaining our market shares and this is something we believed in and I still believe in. We have a close eye on the balance and if it's now going to be moved in one direction or the other, I believe that will mean we'll lose our position and the players will move on.

Both Gustafzon and Kärrbrink resigned and were heavily criticized in the Swedish media. For example, the Swedish daily Svenska Dagbladet wrote in an analysis entitled "High Stakes" (SvD 2008-04-22) that:

Jesper Kärrbrink's journey to the exit this last year has been like that of a kamikaze squeezing his eyes shut and deliberately throttling full-speed ahead toward destruction - with dollar signs on the inside of his eyelids.

\subsection{An unexpected twist: expert praise}

But then came an unexpected twist. A few months later, Svenska Spel was, quite paradoxically, named "the world's most responsible gambling company" based on the market-based responsible gambling development that had occurred under Kärrbrink's and Gustafzon's management. It was at the World Lottery Association congress in Rhodes in October 2008 that a jury comprising CSR experts from various sectors voted to give the company the "WLA Award for Responsible Gambling Excellence", with the motivation that Svenska Spel "overall shows first 
class behaviour in the area of responsible gambling." Svenska Spel also won first prize in the category of best training programme for gambling agents. This expert praise is a nice illustration of the complicated corporate governance matrix a stateowned enterprise like Svenska Spel has to handle. Stake-holders on the national and international arena use different and at times competing government and governance measures to evaluate how the SOE has fulfilled its dual mission. Is increasing profits necessarily a bad thing? What is the view on the commoditization of responsibility, as seen in the market-based decoupling of separate sites, products and services aimed to help consumers self-regulate the externality of the market?

The proof is in the pudding, and despite the prestigious industry award, it was clear that all stake-holders were not equally pleased. A couple of months later, in December 2008 when the public investigation into the future of gambling regulations (SOU 2008:124) was presented, investigators once more saw fit to point out that protection against the social harms of gambling addiction, fraud and criminality should permeate everything from licensing, selling and the launch of new games, to marketing and control (SOU 2008:124 pp. 573, 580). The investigators stressed in particular that "The SOE must shoulder a greater and more obvious responsibility." Or in other words: responsibility should not be decoupled and offered in a separate niche-market for responsible gambling tools, it should permeate the entire organization.

\subsection{A fresh attempt at market-based decoupling: setting up a separate subsidiary}

Ever since the very first responsibility policy in 2004, Svenska Spel had had plans to sell its expertise in responsible gambling technology internationally. From the start, the goal had been to export both games and technical solutions to other state monopolies abroad (Palmgren, interview; Annual reports 2004-2005). At the end of 2004, the Svenska Spel board took a strategic decision to form the "Svenska Spel International" business area. According to board chairman Anders Gustafzon, Svenska Spel held discussions early on with eight countries including the Baltic States, Canada and Austria. The idea was to sell the technology under licence. In the 2006 Annual report (p. 15), for example, the following was written about this ambition:

Svenska Spel's business attracts much international attention, and the poker initiative with our unique responsible gambling solution is of interest to the gambling world. We have commenced a partnership with Lithuania's regulated gambling company Olifeja, which will enable Lithuanian citizens to play games such as Triss and Pick'n'Click in 2007. The beneficiary for the operations is the Lithuanian Olympic Committee. We have also had a number of enquiries about providing our responsible poker under licence to gambling companies in other countries, something which would require permission from the government.

But that permission never came. Rather, the company's international ambitions were criticized, despite the increasing global Internet competition Svenska Spel came to face. It became untenable from a policy standpoint for the government to justify the claim that the purpose of Svenska Spel was to protect Swedish gambling 
in Sweden, and that the ability of others to sell games in the country should therefore be limited, if at the same time Svenska Spel itself would establish itself abroad. Due to the paradoxical EU position taken in the mid-1990s and defended ever since, the price European state-owned gambling companies had to pay for the protection of their monopoly status was an outspoken national limit to their sales.

In March 2010, following the change of board chairs, two CEO replacements and a steady decrease in both profits and market share, Svenska Spel was allowed to challenge the paradoxical EU position or at least to enter its "grey zone" when forming a separate subsidiary, Playscan Limited. This subsidiary was assigned to manage international sales, not of games, but of the Playscan ${ }^{\mathrm{TM}}$ responsible gambling technology, for the expressed purpose of combating gambling problems in the global gambling industry (Olsson, interview; Svenska Spel Annual report 2010). The new company's motto was "healthy gambling is good business". Playscan's first CEO and former part of the CSR team at Svenska Spel, Ann-Sofie Olsson, commented on the efforts invested in spreading the company's responsible gambling tools to regulated gambling companies in Sweden and abroad as follows (Svenska Spel Annual report 2010, 16):

The Playscan ${ }^{\mathrm{TM}}$ responsible gambling tool creates the potential to contribute to the development of long-term sustainability across the international gambling market. We're simply combining a commercial approach with social responsibility.

According to Svenska Spel, the Playscan tool soon stirred "major international interest" (ibid, 16) and, in its 2011 Annual report, Svenska Spel announced that Playscan Limited had now reached agreements with two domestic lotteries A-lotterierna and Miljonlotteriet, as well as three foreign: the French La Française de Jeux, the Finnish RAY, and the Canadian Atlantic Lottery. And these first contracts were soon followed by contracts with Swedish Kombispel and Norwegian Norsk Tipping (www.playscan.com/pages/case, accessed 2013-08-11). In 2013, the company changed CEOs and sales increased at the same time as it launched an upgrade, Playscan 3.7, with improved analytical capabilities for their operators. Playscan also hired renowned gambling researcher Dr Richard Wood, who commenced an evaluation of Playscan's effectiveness as a consumer protection system for the global internet gambling market (www.playscan.com, accessed 2013-08-11). But only two years later, in July 2015, the sensitive venture came to an end as Playscan announced in a press release that the company would merge into Svenska Spel and that the product would no longer be commercially available to new customers. Said Andreas Holmström, CEO of Playscan, in the press release:

Our solution has been ahead of this curve, leading the way, which is really inspiring. However, we see that many operators pursue their own solutions, making demand for an off-the-shelf solution low.

As seen in Table 2, Playscan was never a cash cow for Svenska Spel. It was never a question of big money, nor big risks. In fact, although this was indeed a new venture, the financial results indicate that setting up the company is likely to have served a ceremonial purpose for Svenska Spel, rather than a commercial. 
Table 2 Playscan AB financial results 2010-2014, kSEK

\begin{tabular}{lrrrrr}
\hline & 2010 & 2011 & 2012 & 2013 & 2014 \\
\hline Turnover & 8549 & 8277 & 3836 & 7045 & 9071 \\
Net income & -1342 & -5208 & -8891 & -7391 & 14 \\
\hline
\end{tabular}

All in all, the tricky balancing act of attempting to operate in a global market, yet within a national jurisdiction, had taken its toll on the hybrid organization. At the time of writing this case in the summer of 2016, Svenska Spel rests its case awaiting the results of yet another public inquiry on the future of the Swedish gambling market, with a possible introduction of a licence system that would allow foreign gambling firms with a public licence to legally take their business across the national border. Only time will tell what position a fully state-owned company with a mission to act as a moral role model can successfully take and keep in such a competitive setting. We will not be surprised if we find a renewed emphasis on market-embedded morality, as in sales of "tools" in the global side-market of "responsible gambling".

\section{Conclusion and discussion: decoupling in the age of market- embedded morality}

The findings presented in this article contribute to the theory of hybrid organizations and to a more nuanced understanding of how they, over time, may respond to institutional pressure and a complex dual mission by decoupling, not only within the formal organization (Meyer and Rowan 1977) but also by way of market devices, responsibility labelled products and exchanges in their contested market setting (Shamir 2008; Alexius 2014). The study also contributes to the emerging literature on the dilemma between state ownership and strategy of SOEs (Cuervo-Cazurra et al. 2014). In terms of practical implications, the findings are highly relevant to anyone involved in the corporate governance of an SOE: politicians, public servant owner representatives, board members and managers, although the findings can also be relevant to a wider range of stakeholders for both SOEs and other hybrid organizations. In this final section, we elaborate on the overarching theme of how and why hybrids in particular may respond to calls for responsibility in the age of market-embedded morality.

As was discussed in some detail in the introduction to this paper, hybrid organizations are expected to reach financial and non-financial goals and to satisfy the needs of multiple stakeholders (i.e. costumers, the government, the general public, etc.) (Thomasson 2009; Alexius and Cisneros Örnberg 2015). The tensions over these different goals imposes a cognitive burden on boards and managers that requires an acceptable compromise (Argento et al. 2016). In our contemporary Western business climate there is much talk about realizing the "responsibility capital" (Sjöström and Sweet 2010) of corporations, and a growing body of CSR consultants and concerned internal leaders take part in driving the push to help 
organizations become permeated with responsibility (Windell 2006; Jutterström and Norberg 2013; Alexius et al. 2017). This is because, to be perceived as legitimate in the long run, market actors-and in particular corporations-must make and justify claims to be actors with morality (Zelizer 1979; Fourcade and Healy 2007). However, when taking a closer look at the actual practices of corporate responsibility, particularly in organizations with complex missions, we find that it is more common than not that the official ambition of a permeating responsibility is translated and diluted.

In light of the case findings presented in this paper, like all hybrid organizations, SOEs can harvest legitimacy-enhancing elements of potentially conflicting institutional logics such as political and market logics. However, as the case on Svenska Spel clearly demonstrates, this is a complicated balancing act that risks backfiring. Around the year 2000, the ongoing expansion of online gambling became a worrisome threat to government monopolies around the world. How would national monopoly regulation (such as the Swedish Lotteries Act), be able to handle globalization of the gambling market? As a nationally regulated, fully state-owned firm in a rapidly digitalized, globalizing contested market with increasingly fierce competition in the e-gambling segment, Svenska Spel found itself in the difficult position of what could be called a "government/governance matrix of responsibility organizing", characterized by multiple stakeholders with conflicting interests and expectation and views on how Svenska Spel should aim to fulfill competing objectives and expectations from the government and from the market (Oliver 1991). In the political sphere, national and EU politicians and public authorities drew on traditional organizational elements such as membership and hierarchy (EU), and rules (both national legislation and EC regulation), as well as formal monitoring and sanctions (national public agencies, the ECJ and the commission). In the market sphere on the other hand, claims to responsibility and corporate morality were justified with reference to a multitude of standards, tools and NGO awards. Despite a clearly outspoken ambition—in fact a raison d'être-to have responsibility permeate the SOE, the complexity of the dual mission of "responsible gambling" and its underlying conflicting values (of profit making and public health achievements) quickly prompted Svenska Spel to start decoupling.

At first Svenska Spel used what we in this paper have called organization-based decoupling (decoupling within a formal organization), following Meyer and Rowan (1977). By adopting a special CSR policy, by setting up a CSR team and by appointing a CSR manager, Svenska Spel was able to continue to apply for permits for new games and to push profitability by way of a "green growth" ambition (selling a little more to the many, rather than a lot to problem gamblers). At the outset (in 2004-2005), Svenska Spel also introduced a number of responsibility measures traditionally associated with the political sphere of government, such as age limits and marketing restrictions.

However, when faced with the rapidly digitalized global competition, over the next couple of years, Svenska Spel's response changed its emphasis from organization-based decoupling to what we have defined as marked-based decoupling, as seen in the gradual outward and downward shift of responsibility from the organizational context of the firm to the consumers in the market context (Miller 
and Rose 1990; Rose 1999). In empirical practice, this meant that the organizing site of "responsible gambling" in Svenska Spel shifted from the board room to the communications department, via a niche range of responsibility-labelled games and a separate site with specialized responsible gambling e-tools, out to a separate subsidiary (Playscan Limited) targeting both national and international gambling operators. The conceptual distinction between organization-based and market-based decoupling is not only structural however. It is also a matter of shifting logics as seen when Svenska Spel increasingly referred to a prospective logic for distributing responsibility in the market, a logic according to which it could be legitimate for a producer of games to take on a role as an educator and provider of advice and tools for responsible gambling. Advice and tools that are created with the specific intent of enabling consumers to take responsibility by changing their gambling habits. All in all, this means that the behaviour on which the hybrid organization bases its legitimacy changed as a market logic was employed.

We suggest that the temptation to make such claims to market-embedded morality may be referred to not only as a suitable response to the global competition and as a sign of conformation to modern ways of organizing gambling firms, but also as a measure that conflicts less with the profit-making objective of the hybrid organization. This is because selling responsible gaming devices and tools to other gambling operators world-wide did not hinder Svenska Spel from continuing to sell its risky games to consumers at home. Also, making these risk-reducing tools available to operators did not mean consumers at risk were actually using them (Alexius 2017). But nevertheless, market-embedded morality (embedded in tools such as Playscan ${ }^{\mathrm{TM}}$ in processes of commodification and responsibilization) provided the operators with much needed legitimacy.

It is important to note that these findings from a Swedish SOE operating in the gambling market may well be generalizable to many other hybrid organizations positioned at the crossroads of political/government and market/governance schemes of responsibility organizing. Although the aim of this article is not to provide generalizability but rather to suggest conceptual refinement based on a rich empirical case, we encourage scholars to explore the frequency and consequences of hybrid organizations seeking legitimacy not only by organization-based decoupling but also, and perhaps increasingly, by marked-based decoupling responses.

If this is indeed an expanding phenomenon, it also becomes crucial to analyse to what extent we should trust that such emerging niche products and side markets actually solve or handle the problems and value conflicts at stake. As suggested by Fourcade and Healy (2007) and Shamir (2008), we must continue to scrutinize the outcomes of these corporate claims to market-embedded morality.

Given today's increasing mediatization and demands for transparency, not least as concerns the responsibility work of SOEs, the need to defend the organization against criticism can be devastating for its reputation if it comes to light that the hybrid organization is, in effect, protecting its core business from responsibility claims (Grafström et al. 2013). The ending of the Svenska Spel case offers a neat illustration of how marked-based decoupling may not offer the same degree of legitimacy with the stakeholders/general public as organization-based decoupling does. In this case, it became untenable from a policy standpoint to claim that the 
purpose of Svenska Spel was to protect Swedish gamblers in Sweden, and that the ability of others to sell games should therefore be limited, at the same time as Svenska Spel itself was noting record national poker sales and had plans to establish itself abroad. The EU Commission had on repeated occasions accused the Swedish state of hypocrisy and threatened to bring Sweden before the ECJ if the Minister of Finance failed to demonstrate that the Swedish state was demonstrating responsibility, a Svenska Spel that protected its citizens-not a gambling company whose sole purpose was to make money.

Considering these empirically based insights, we conclude with a call for future studies of hybrid organizations and their decoupling attempts to scrutinize the popular rhetoric of market-embedded morality as an "empowerment", "service", etc. to customers. It may well be that this discourse and its responsibilization of consumers contributes to protect the hybrid organization against hypocrisy which in turn may make market-based decoupling an increasingly popular response. Although the ethnographical method used in this paper does not lend itself well to generalizations, we have little reason to believe that Svenska Spel is a "unique" case. In a future comparative study comprising a wider selection of hybrid organization (for example SOEs), it would be worthwhile to consider exploring how variations in factors such as market orientation and competition, the political sensitivity of the product or service and the degree of perceived risks posed to consumers affect the use and outcomes of the strategic response of market-based decoupling.

Open Access This article is distributed under the terms of the Creative Commons Attribution 4.0 International License (http://creativecommons.org/licenses/by/4.0/), which permits unrestricted use, distribution, and reproduction in any medium, provided you give appropriate credit to the original author(s) and the source, provide a link to the Creative Commons license, and indicate if changes were made.

\section{References}

Adams, C. A., \& Larrinaga-Gonzalez, C. (2007). Engaging with organisations in pursuit of improved sustainability accounting and performance. Accounting, Auditing \& Accountability, 20, 333-355.

Alexius, S. (2014). Ansvar och marknader (Responsibility and markets). Stockholm: Liber.

Alexius, S. (2017). Assigning responsibility for gambling-related harm: Scrutinizing processes of direct and indirect consumer responsibilization of gamblers in Sweden. Addiction Research and Theory (accepted for publication, forthcoming).

Alexius, S., Castillo, D., \& Rosenström, M. (2014). Contestation in transition-Value configurations and market reform in the markets for gambling, coal and alcohol. In S. Alexius, \& K. Tamm Hallström (Eds.), Configuring value conflicts in markets. Cheltenham: Edward Elgar.

Alexius, S., \& Cisneros Örnberg, J. (2015). Mission(s) impossible? Configuring values in the governance of state-owned enterprises. International Journal of Public Sector Managment, 32, 286-306.

Alexius, S., Furusten, S., \& Werr, A. (2017). As flies around goodies-The rise of experts and services in the emerging field of CSR and sustainability. In S. Furusten \& A. Werr (Eds.), The organization of the expert society. London: Routledge.

Alexius, S., \& Tamm Hallström, K. (Eds.). (2014). Configuring value conflicts in markets. Cheltenham: Edward Elgar.

Arellano-Gault, D., Demortain, D., Rouillard, C., \& Thoenig, J.-L. (2013). Bringing public organization and organizing back. Organization Studies, 34, 145-167. 
Argento, D., Culasso, F., \& Truant, E. (2016). Competing logics in the expansion of public service corporations. Utilities Policy, 40, 125-133.

Bacchi, C. L. (2009). Analysing policy: What's the problem represented to be?. Melbourne: Pearson Education Australia.

Baden, D. \& Harwood, I. A. (2012). Terminology matters: A critical exploration of corporate social responsibility terms. Journal of Business Ethics, 116(3), 615-627.

Battilana, J., \& Dorado, S. (2010). Building sustainable hybrid organizations: The case of commercial microfinance organizations. Academy of Management Journal, 53, 1419-1440.

Battilana, J., \& Lee, M. (2014). Advancing research on hybrid organizing-Insights from the study of social enterprises. The Academy of Management Annals, 8, 397-441.

Beronius, M. (1991). Genealogi och sociologi. Nietzsche, Foucault och den sociala analysen. Stockholm: Brutus Östling bokförlag.

Bexell M. (2005). Exploring responsibility: Public and private in human rights protection [unpublished dissertation]. Lund (Sweden): Lund University, Department of Political Science.

Brooks, S. (2010). CSR and the straitjacket of economic rationality. International Journal of Sociology and Social policy, 11, 604-617.

Billis, D. (2010). Towards a theory of hybrid organizations. In D. Billis (Ed.), Hybrid organizations and the third sector: Challenges for practice, theory and policy (pp. 46-69). New York: Palgrave Macmillan.

Bromley, P., \& Meyer, J. (2015). Hyper-organization: Global organizational expansion. Oxford: Oxford University Press.

Brunsson, N. (1994). Politization and 'company-ization'. Management Accounting Research, 5, 323-335.

Brunsson, N., et al. (2015). Att organisera marknader. Stockholm: Makadam Press.

Bruton, G. D., Peng, M. W., Ahlstrom, D., Stan, C., \& Xu, K. (2015). State-owned enterprises around the world as hybrid organizations. Academy of Management Perspectives, 29, 92-114.

Buck, T., \& Shahrim, A. (2005). The translation of corporate governance changes across national cultures: the case of Germany. Journal of International Business Studies, 36, 42-61.

Cowan, R., \& Rizzo, M. J. (1995). Profits and morality. Chicago: The University of Chicago Press.

Christiansen, H. (2013), Balancing Commercial and Non-Commercial Priorities of State-Owned Enterprises. OECD Corporate Governance Working Papers, No. 6. OECD Publishing. http://dx. doi.org/10.1787/5k4dkhztkp9r-en.

Czarniawska, B., \& Sévon, G. (Eds.). (1996). Translating organizational change. Berlin: Walter de Gruyter.

Cuervo-Cazurra, A., Inpen, A., Musacchio, A., \& Ramaswamy, K. (2014). Governments as owners: Stateowned multinational companies. Journal of International Business Studies, 45, 919-942.

Davies, B., \& Harré, R. (2001). Positioning: The discursive production of selves. In M. Wetherell, S. Taylor, \& S. J. Yates (Eds.), Discursive theory and practice: A reader. London: Sage.

De Geer, H. (2011). Statens spel: Penninglotteriet, Tipstjänst. Stockholm: Svenska Spel.

De Goede, M. (2005). A genealogy of finance: Virtue, fortune and faith. Minneapolis, MN: University of Minnesota Press.

Denis, J.-L., Ferlie, E., \& Van Gestel, N. (2015). Understanding hybridity in public organizations. Public Administration, 93, 273-289.

Donzelot, J. (1991). The mobilization of society. In G. Burchell, C. Gordon, \& P. Miller (Eds.), The Foucault effect: Studies in governmentality (pp. 169-179). Chicago: University of Chicago Press.

Ebrahim, A., Battilana, J., \& Mair, J. (2014). The governance of social enterprises: Mission drift and accountability challenges in hybrid organizations. Research in Organizational Behavior, 34, 81-100.

Eisenhardt, K. M. (1989). Building theories from case study research. Academy of Management Review, 14, 532-550.

Espeland, W., \& Stevens, M. (1998). Commensuration as a social process. Annual Review of Sociology, 24, 312-343.

Fiss, P. C., \& Zajac, J. (2004). The diffusion of ideas over contested terrain: the (non)adoption of a shareholder value orientation among German firms. Administrative Science Quarterly, 49, 501-534.

Fiss, P. C., \& Zajac, E. J. (2006). The symbolic management of strategic change: sense giving via framing and decoupling. Academy of Management Journal, 49, 1173-1193.

Forsström, P. (2010). Sveriges kamratföreningar är unika i sitt slag. In P. Binde \& J. Jonsson (Eds.), Spelberoendes riksförbund 10 år - en jubiléumsskift. Östersund: Swedish National Institute for Public Health. 
Fourcade, M., \& Healy, K. (2007). Moral views of market society. Annual Review of Sociology, 33, 285-311.

Garsten, C., \& Sörbom, A. (2014). Values aligned: the organization of conflicting values within the World Economic Forum. In S. Alexius \& K. Tamm Hallström (Eds.), Configuring value conflicts in markets (pp. 159-177). Cheltenham: Edward Elgar.

Geiger, S., Harrison, D., Kjellberg, H., \& Mallard, A. (2015). Concerned markets: Economic ordering for multiple values. Cheltenham: Edward Elgar.

Grafström, M., Petrélius, P., \& Windell, K. (2013). Föredöme eller fördömd? Medierna som moralisk domstol. Stockholm: SNS Publishing.

Greenwood, R., \& Hinings, C. R. (1996). Understanding radical organizational change: Bringing together the old and the new institutionalism. Academy of Management Review, 21, 1022-1054.

Greenwood, R., Raynard, M., Kodeih, F., Micelotta, E. R., \& Lounsbury, M. (2011). Institutional complexity and organizational responses. The Academy of Management Annals, 5(1), 317-371.

Grossi, G., Papenfuß, P., \& Tremblay, M. S. (2015). Corporate governance and accountability of stateowned enterprises. Relevance for science and society and interdisciplinary research perspectives. International Journal of Public Sector Management, 28(4/5), 274-285.

Grossi, G., \& Thomasson, A. (2015). Bridging the accountability gap in hybrid organizations: the case of Copenhagen Malmö Port. International Review of Administrative Sciences, 81, 604-620.

Helling, S. (2003). Det är som ett kärleksförhållande: spelmissbruk bland unga. Stockholm: Swedish Council for Information on Alcohol and Other Drugs (CAN), Report No. 0283-1198.

Hong, H., \& Kacpercyk, M. (2009). The price of sin: The effects of social norms on markets. Journal of Financial Economics, 93, 15-36.

Hockerts, K. (2015). How hybrid organizations turn antagonistic assets into complementarities. California Management Review, 57, 83-106.

Husz, O. (2004). Drömmars värde Varuhus och lotteri i svensk konsumtionskultur 1897-1939. Möklinta: Gidlunds förlag.

Ihrfors, R. (2007). Spelfrossa: spelets makt och maktens spel. Doctoral Dissertation in business studies, Stockholm Business School, Stockholm University.

Jonas, H. (1984). The imperative of responsibility: In search of an ethics for the technological age. Chicago: University of Chicago Press.

Jutterström, M., Alexius, S., \& Rosenström, M. (2014). Intervention markets and market re-organization. In Paper presented at the international Score conference Organizing markets, Stockholm School of Economics, 16-17 October 2014.

Jutterström, M., \& Norberg, P. (Eds.). (2013). CSR as a management idea-Ethics in action. Cheltenham: Edward Elgar.

Kallio, T. J. (2007). Taboos in corporate social responsibility discourse. Journal of Business Ethics, 74, $165-175$.

Koppell, J. G. S. (2003). The politics of quasi-government: Hybrid organizations and the dynamics of bureaucratic control. Cambridge: Cambridge University Press.

Kraatz, M. S., \& Block, E. S. (2008). Organizational implications of institutional pluralism. In R. Greenwood, C. Oliver, K. Sahlin, \& R. Suddaby (Eds.), The Sage handbook of organizational institutionalism (pp. 243-275). London: Sage Publications.

MacLean, T., \& Behnam, M. (2010). Organizations: The dangers of decoupling: The relationship between compliance programs, legitimacy perceptions, and institutionalized misconduct. Academy of Management Journal, 53, 1499-1520.

Meyer, J. W. (1996). Otherhood: The promulgation and transmission of ideas in the modern organizational environment. In B. Czarniawska \& G. Sevón (Eds.), Translating organizational change. Berlin: Walter de Gruyter.

Meyer, J., \& Rowan, B. (1977). Institutionalized organizations: Formal structure as myth and ceremony. American Journal of Sociology, 83, 340-363.

Miller, D. (2001). Distributing responsibilities. Journal of Political Philosophy, 9, 453-471.

Miller, P., \& Rose, N. (1990). Governing economic life. Economy and Society, 19, 131-162.

Miller, P., \& Rose, N. (1997). Mobilizing the consumer: assembling the subject of consumption. Theory, Culture and Society, 14, 1-36.

Newman, J. (2001). Modernising governance. London: Sage.

Nyqvist, A., \& Thedvall, R. (2014). Polarization and convergence of values at the intermediary position. In S. Alexius \& K. Tamm Hallström (Eds.), Configuring value conflicts in markets (pp. 145-158). Cheltenham: Edward Elgar. 
OECD. (2003). Managing conflict of interest in the public service: OECD guidelines and country experiences. Paris: OECD publishing. https://www.oecd.org/gov/ethics/48994419.pdf.

OECD. (2011). SOE governance reform: An inventory of recent change. Paris: OECD publishing. http:// www.oecd.org/daf/ca/corporategovernanceofstate-ownedenterprises/state-ownedenterprisegovernancere formaninventoryofrecentchange.htm.

OECD. (2015). OECD guidelines on corporate governance of state-owned enterprises (2015 th ed.). Paris: OECD Publishing. doi:10.1787/9789264244160-en.

Oliver, C. (1991). Strategic responses to institutional processes. Academy of Management Review, 16(1), 145-179.

O’Malley, P. (1996). Risk and responsibility. In A. Barry, T. Osborne, \& N. Rose (Eds.), Foucault and political reason: Liberalism, neo-liberalism and rationalities of government (pp. 189-207). London: UCL Press.

Ortiz, L. (2006). Till spelfriheten! Manual för behandling individuellt eller i grupp. Stockholm: Natur and Kultur.

Otley, D., \& Berry, T. (1994). Case study research in management accounting and control. Management Accounting Research, 5(1), 45-65.

Pache, A. C., \& Santos, F. (2010). When worlds collide: The internal dynamics of organizational responses to conflicting institutional demands. Academy of Management Review, 35, 455-476.

Pache, A.-C., \& Santos, F. (2013). Inside the hybrid organization: Selective coupling as a response to competing institutional logics. Academy of Management Journal, 56, 972-1001.

Powell, W. W., \& DiMaggio, P. (Eds.). (1991). The New institutionalism in organizational analysis. Chicago: The University of Chicago Press.

Radon, J., \& Thaler, J. (2005). Resolving conflicts of interest in state-owned enterprises. International Social Science Journal, 57(S1), 11-20.

Rainey, H. G., \& Chun, Y. H. (2005). Public and private management compared, Chapter 4. In E. Ferlie, L. E. Lynn, \& C. Pollitt (Eds.), The Oxford handbook of public management (pp. 72-103). Oxford: Oxford University Press.

Reith, G. (1999). The age of chance: Gambling in western culture. London: Routledge.

Rose, N. (1999). Powers of freedom: Reframing political thought. Cambridge: Cambridge University Press.

Scott, W. R. (2014). Institutions and organizations. Thousand Oaks, CA: Sage Publications.

Shamir, R. (2008). The age of responsibilization: On market-embedded morality. Economy and Society, $37,1-19$.

Sjöström, E., \& Sweet, S. (2010). Det ansvarsfulla kapitalet-CSR på finansmarknaden. In F. Wijkström (Ed.), Idéer för framtiden: Tankar på vägen in $i$ det nya sparbankslandet. Lidköping: Sparbanksakademien.

Scapens, R. W. (2004). Doing casy study research. In C. Humphrey, R. W. Scapens, \& B. Lee (Eds.), The real life guide to accounting reserach: A behind-the-scenes view of using qualitative research methods (pp. 257-279). Amsterdam: Elsevier Ltd.

Skelcher, C., \& Smith, S. R. (2015). Theorizing hybridity: Institutional logics, complex organizations and actor identities: The case of non-profits. Public Administration, 93, 433-448.

Smith, N. C. (1990/2015). Morality and the market: Consumer pressure for corporate accountability. New York: Routledge.

Stymne, A. (2010). Att förebygga spelproblem, Chapter 6. In P. Binde \& J. Jonsson (Eds.), Spelberoendes riksförbund 10 år - en jubiléumsskift. Östersund: National Institute for Public Health.

Suchman, M. C. (2005). Managing legitimacy: Strategic and institutional approaches. Academy of Management Review, 20, 571-610.

Thomasson, A. (2009). Exploring the ambiguity of hybrid organisations: a stakeholder approach. Financial Accountability and Management, 25, 353-366.

Thornton, P. H., \& Ocasio, W. (2008). Institutional logics. In R. Greenwood, C. Oliver, R. Suddaby, \& K. Sahlin-Andersson (Eds.), The Sage handbook of organizational institutionalism. London: Sage.

Vining, A. R., \& Weimer, D. L. (2016). The challenges of fractionalized property rights in public-private hybrid organizations: the good, the bad and the ugly. Regulation and Governance, 10, 161-178.

Windell, K. (2006). Corporate social responsibility under construction: Ideas, translations and institutional change. Doctoral Dissertation in business studies. Uppsala University.

Yoshikawa, T., Tsui-Auch, L. S., \& McGuire, J. (2007). Corporate governance reform as institutional innovation: the case of Japan. Organization Science, 18, 973-988. 
Zelizer, V. (1979). Morals and markets: The development of life insurance in the United States. New York: Columbia University Press.

Zelizer, V. (1985). Pricing the priceless child: The changing social value of children. Princeton: Princeton University Press.

Zelizer, V. (2005). The purchase of intimacy. Princeton: Princeton University Press.

\section{Interviews}

Interviews cited in this paper were conducted during the period 2007-2010. The interviewees cited or referred to in the case are listed below in alphabetical order according to surname, with their title at the time of the interview or as indicated. A total of 40 interviews, of which 18 were with Svenska Spel managers and staff, informed the account (see methods section in text).

Cederberg, Niclas. Project manager, "Project P" (later PlayScan), Svenska Spel. 2008-03-14.

Forsström, Petra. Head of CSR, Svenska Spel. 2008-01-16.

Gustafzon, Anders. Former board chair, Svenska Spel. 2010-08-16.

Jansson, Andreas. Communications director, Svenska Spel. 2008-01-22.

Kärrbrink, Jesper. CEO, Svenska Spel, Interview 1: 2007-10-29.

Interview 2: 2010-05-31 (retrospect interview, at the time CEO at Eniro).

Olsson, Anne-Sofie. CEO, Svenska Spel's subsidiary Playscan AB. 2010-09-13.

Palmgren, Bengt. Chief legal counsel, Svenska Spel. 2010-08-18.

Schubert, Maria. Project manager for CSR issues, Svenska Spel. 2008-01-24.

\section{Corporate reports and press releases}

Svenska Spel CSR Report 2004 "Svenska Spel i samhället" [Svenska Spel in society].

Svenska Spel Annual reports 2005-2015.

\section{Press releases}

Svenska Spel (2008). Jesper Kärrbrink lämnar Svenska Spel efter starkt första kvartal [Jesper Kärrbrink exits Svenska Spel following strong first quarter]. Press release from Svenska Spel, 2008-04-21. http://www.mynewsdesk.com/se/pressroom/svenska_spel/pressrelease/view/jesper-kaerrbrink-laemnarsvenska-spel-efter-starkt-foersta-kvartal-209722.

Playscan (2005). Playscan AB merges into Svenska Spel AB. Press release from Playscan 2015-07-02. http://playscan.com/playscan-ab-merges-into-svenska-spel-ab/.

\section{Public official documents}

EC Treaty: Article 43 (Access to European Union Law: http://eur-lex.europa.eu/homepage.html?locale= en).

EC Treaty: Article 49 (Access to European Union Law: http://eur-lex.europa.eu/homepage.html?locale= en).

\section{EC/EU Court rulings}

Gambelli (C-243/01, 6 November 2003) http://curia.europa.eu/juris/liste.jsf?language=en\&num=C-243/01 . Läärä (C-124/97, 21 September 1999) http://curia.europa.eu/juris/liste.jsf?language=en\&jur=C,T,F \&num=c-124/97\&td=ALL. 
Ministry of Finance (2008). Margareta Winberg nomineras till ny ordförande för Svenska Spel [Margareta Winberg named Svenska Spel's new board chair]. Press release, 2008-04-04. http:// www.mynewsdesk.com/se/view/pressrelease/margareta-winberg-nomineras-till-ny-ordfoerande-foersvenska-spel-206087, published 2007-06-12.

Schindler (C-275/92, 24 March 1994) http://curia.europa.eu/en/content/juris/c2_juris.htm.

SOU 2000:50. Från tombola till internet - översyn av lotterilagstiftningen (From raffles to the Internet - a review of legislation on lotteries). Ministry of Finance. Report from the Lotteries Act Commission. Stockholm: Allmänna förlaget.

SOU 2006:11. Spel $i$ en föränderlig värld [Gambling in a changing world]. Report from the Lottery Commission. Stockholm: Fritzes offentliga publikationer.

SOU 2008:124. En framtida spelreglering [Gambling regulation for the future]. Report from the Gambling Commission. Stockholm: Fritzes offentliga publikationer.

SOU 2012:14. Ekonomiskt värde och samhällsnytta - förslag till en ny statlig ägarförvaltning [Economic value and social good - proposals for a new state corporate governance]. Report from the State Ownership Commission. Stockholm: Fritzes offentliga publikationer.

Zenatti (C-67/98, 21 October 1999) http://curia.europa.eu/juris/liste.jsf?language=en\&num=C-67/98.

\section{Media: newspapers and online news sources}

Svenska Dagbladet $(S v D)$. "Töm och betsel på spelbolagen” [Reining in the gambling companies], by Maria Larsson and Anders Borg. Published 2007-06-20.

Svenska Dagbladet $(S v D)$. "Vi tycker olika" [We're of different opinions], by Irene Sokolow. Published 2008-04-21.

Svenska Dagbladet (SvD). "Högt spel” [High stakes], by Jonas Fröberg. Published 2008-04-22.

TT. "Winberg ny ordförande för Svenska Spel” [Winberg Svenska Spel's new board chair]. Published 2008-04-04.

Agenda, 2008-05-22 (TV broadcast. News story on the gambling market).

Susanna Alexius is Assistant Professor in Business Administration at the Stockholm Centre for Organizational Research (Score) at Stockholm University and Stockholm School of Economics (Sweden). Alexius's research focuses on the organization of markets, hybrid organizations and public governance and performance.

Giuseppe Grossi is Professor in Public Management and Accounting at the Department of Business Administration and Work Science, Kristianstad University (Sweden). Grossi's research focuses on public governance and performance, hybrid organizations, and smart cities. 